\title{
Preventive Maintenance Characteristics towards Optimal Maintenance Performance: A Case Study of Office Buildings
}

\author{
Cheong Peng Au-Yong, Azlan Shah Ali, Faizah Ahmad \\ Faculty of Built Environment, University of Malaya, Kuala Lumpur, Malaysia \\ Email: auyongcp@um.edu.my
}

Received May 2014

\begin{abstract}
Lack of preventive measure is currently the problem that implicates poor building maintenance performance and issue on sustainability of buildings in Malaysia. Whereby, preventive maintenance is an effective approach to enhance the reliability and quality of a system and its components. This study seeks to investigate the characteristics of preventive maintenance towards the overall performance in building maintenance. Case study approach is adopted to identify the maintenance characteristics and aspects that lead to good performance. The research findings demonstrate that the most significant maintenance characteristics towards overall performance are skill and knowledge of maintenance labour, quality of spare parts and materials, length of predetermined maintenance interval, skill and knowledge of maintenance manager, capability to adopt maintenance equipment and technique, budget allocation for acquisition of maintenance data, reliability of maintenance data, as well as frequency of monitoring and inspection. As a conclusion, the significant maintenance characteristics must be taken into consideration to achieve optimal maintenance performance. In order to improve the effectiveness of maintenance strategy and the maintenance performance, the study recommends practice and provision of communication platform such as meeting and customer satisfaction survey that involves all the key participants from clients to customers.
\end{abstract}

\section{Keywords}

Office Building, Maintenance Management, Preventive Maintenance, Maintenance Characteristic, Maintenance Performance

\section{Introduction}

Poor building maintenance is one of the most concerned problems in construction industry. This problem becomes an obstacle to achieve sustainable building. Thus, maintenance management is seen as an approach to tackle the problem. Horner et al. [1] stated that the objective of maintenance management is to reduce or even avoid the reactive maintenance by proper planning and implementation of maintenance tasks using appropriate materials and tools at the right time. However, in Malaysia, low service quality is the main current issue of 
maintenance management [2] [3]. The issue is due to the failures in planning of maintenance strategies or tactics caused by several factors such as lack of knowledge about the maintenance strategies, inadequate performance standard, lack of building performance monitoring data, failure to provide appropriate advice on design and planning based on overall performance, and others. As a result, many buildings are found to be unfit in terms of building use and function.

Lack of preventive measure is currently the problem that implicates poor maintenance performance. Thus, the research introduces and recommends the implementation of preventive maintenance to tackle the issue. According to Moghaddam and Usher [4] and Wang and Christer [5], preventive maintenance involves maintenance tasks such as inspection, monitoring, cleaning, lubrication, adjustment, alignment, repair, replacement and maintenance of building's and systems' components before failures or system breakdowns occur. Meanwhile, preventive maintenance is based on component reliability characteristics and aimed to reduce the probability of component failure, as well as to minimise the system downtime [1] [6]-[8]. The researchers further explained that the cost of preventive maintenance is definitely less than the cost of failure or corrective maintenance. This is because corrective maintenance arises immediately with unexpected and extensive need of maintenance resources [9].

\section{Importance of Preventive Maintenance}

Rao [10] described that preventive maintenance is an effective approach to enhance the reliability and quality of a system and its components. In order to prevent failure from occurring, preventive maintenance practice should be able to indicate when a maintenance work needs to be performed [7]. Eti et al. [11] supported that maximising components reliability and extending the components' life are the main purpose of preventive maintenance. It also provides a critical service function that minimises interruptions to core business of an organisation.

Eti et al. [11] pointed out that system failure causes negative impacts to the organisations, users and customers. The negative impacts could be on the aspects of output, safety, environmental integrity, system quality, customer satisfaction, and additional repair cost incurred. Thus, the implementation of preventive maintenance is necessary to replace the need of corrective maintenance [12]. Consequently, unnecessary cost such as emergency repair cost after occurrence of failure occurs can be reduced or avoided. The required capital investment on maintenance can be minimised as well.

However, Moghaddam and Usher [4] argued that preventive maintenance involve a basic trade-off between the contradict aims, which are to minimise total maintenance costs and to maximise the overall reliability of the building and systems. For example, systems or components that are maintained or replaced frequently will require high maintenance cost, but they will provide high reliability. So, a balance between the two aims must be reviewed and obtained in order to achieve the effectiveness of preventive maintenance. Consequently, this study seeks to investigate the characteristics of preventive maintenance towards the overall performance in building maintenance.

\section{Characteristics of Preventive Maintenance}

Commonly, preventive maintenance is divided into two strategies, which are scheduled maintenance and condition-based maintenance [7] [13]-[15]. It is highly recommended to implement and prioritise both of the maintenance strategies instead of corrective maintenance, to achieve optimal maintenance performance. Through literature review, the characteristics of preventive maintenance are identified as follows [16]:

- Maintenance labour

- Spare parts and materials

- Predetermined maintenance interval

- Failure and maintenance downtime

- Maintenance manager

- Maintenance equipment and technique

- Acquisition of maintenance data

- Monitoring and inspection

The characteristics are likely to influence the overall maintenance performance [17] [18]. Thus, they must be concerned in the maintenance management. An effective maintenance management always put a lot of effort towards these characteristics. 
The significance of the maintenance characteristics in effective maintenance management is revealed by the researchers [16]. However, the question is whether the characteristics are the significant contributors to the overall maintenance performance or not. Therefore, investigate relationship between the maintenance characteristics and the overall maintenance performance is the main objective of this research.

\section{Maintenance Performance Measurement}

Measurement of maintenance performance is an assessment that helps to identify the strengths and weaknesses of the maintenance activities [19]. In addition, the result of performance measurement indicates the effectiveness of existing maintenance strategy. Basically, the measurement of performance can be obtained through the level of success or failure in terms of schedule, cost and functionality [20] [21].

Indeed, customer's satisfaction survey is one of the most popular performance measuring systems, whether in business, product or service sectors [22] [23]. Thus, the concept is also adopted in maintenance management. Feedback in terms of maintenance time, cost and quality from the building users or customers is taken into consideration in the survey to measure the maintenance performance of a building.

Consequently, the overall maintenance performance is determined by the users' and customers' satisfaction towards the maintenance management in this research.

\section{Research Design}

This research adopted case study approach that was adopted by Myeda et al. [24]. Four high-rise office buildings located in Kuala Lumpur were selected for the case study. In the previous customer satisfaction survey report towards maintenance management, the buildings obtained $80 \%$ or above of satisfactory feedback. Thus, they were deemed to have good maintenance performance. Then, study about the concern and commitment towards the maintenance characteristics by the maintenance management, was documented. The aim of the research design is to identify the maintenance characteristics and aspects that lead to good performance.

Several approaches were used to collect the research data, included focused interview, archived documentation, and observation. Semi-structured interview was conducted to understand the relationship between variables [25]. The interview was targeted to the maintenance managers of the selected buildings. In general, questions about the aspects of the maintenance characteristics that influencing the maintenance performance were asked and discussed with the managers. Then, Nik Mat [26] stated that it is constructive to assess the archived documents and records from respective organisations to get the scenario of maintenance management. So, archive documentation was carried out to record the historical data that were related to the maintenance characteristics and their aspects. Furthermore, observation is very high validity because it involves studying the phenomena of cases in natural contexts [25]. Thus, it was performed to track the actual scenario of the maintenance management and performance in the selected buildings. Consequently, all the collected data were combined and discussed accordingly. Combination of the data collected from different approaches could help to increase the reliability and validity of the findings.

\section{Research Result}

All the aspects of maintenance characteristics were examined thoroughly. Then, the findings of the aspects were tabulated in Table 1. The findings revealed the concern and commitment of the management towards each aspect of the maintenance characteristics in the selected buildings.

From the result, it is summarised that the most significant maintenance characteristics towards overall performance are:

- Skill and knowledge of maintenance labour

- Quality of spare parts and materials

- Length of predetermined maintenance interval

- Skill and knowledge of maintenance manager

- Capability to adopt maintenance equipment and technique

- Budget allocation for acquisition of maintenance data

- Reliability of maintenance data

- Frequency of monitoring and inspection 
Table 1. Aspects of maintenance characteristics to achieve optimal performance.

\begin{tabular}{|c|c|c|c|c|c|}
\hline \multirow{2}{*}{ Aspect of Maintenance Characteristic } & \multicolumn{4}{|c|}{ Building } & \multirow{2}{*}{ Percentage (\%) } \\
\hline & B1 & B2 & B3 & B4 & \\
\hline \multicolumn{6}{|l|}{ 1) Maintenance labour } \\
\hline - Amount of salary for maintenance labour is satisfactory & $\mathrm{N}$ & $\mathrm{Y}$ & $\mathrm{Y}$ & $\mathrm{Y}$ & 75 \\
\hline $\begin{array}{l}\text { - Specific qualification and experience are required upon employment of } \\
\text { maintenance labour }\end{array}$ & $\mathrm{Y}$ & $\mathrm{Y}$ & $\mathrm{Y}$ & $\mathrm{Y}$ & 100 \\
\hline - Standby maintenance labour is provided & $\mathrm{Y}$ & $\mathrm{N}$ & $\mathrm{N}$ & $\mathrm{Y}$ & 50 \\
\hline \multicolumn{6}{|l|}{ 2) Spare parts and materials } \\
\hline - Budget allocated for spare parts acquisition is sufficient & $\mathrm{Y}$ & $\mathrm{Y}$ & $\mathrm{Y}$ & $\mathrm{N}$ & 75 \\
\hline - Proper stock of spare parts and materials is stored & $\mathrm{Y}$ & $\mathrm{Y}$ & $\mathrm{Y}$ & $\mathrm{N}$ & 75 \\
\hline - Quality of spare parts and material is guaranteed & $\mathrm{Y}$ & $\mathrm{Y}$ & $\mathrm{Y}$ & $\mathrm{Y}$ & 100 \\
\hline \multicolumn{6}{|l|}{ 3) Predetermined maintenance interval } \\
\hline - Additional budget for routine maintenance is allocated (outsourced contractor) & $\mathrm{N}$ & $\mathrm{N}$ & $\mathrm{N}$ & $\mathrm{Y}$ & 25 \\
\hline $\begin{array}{l}\text { - Interval of routine maintenance (replacement) is fixed according to priority of } \\
\text { systems and components (daily, weekly, monthly, yearly, and etc.) }\end{array}$ & $\mathrm{Y}$ & $\mathrm{Y}$ & $\mathrm{Y}$ & $\mathrm{Y}$ & 100 \\
\hline \multicolumn{6}{|l|}{ 4) Failure and maintenance downtime } \\
\hline $\begin{array}{l}\text { - Additional budget to repair damaged systems and components is allocated } \\
\text { (contingency cost) }\end{array}$ & $\mathrm{N}$ & $\mathrm{N}$ & $\mathrm{Y}$ & $\mathrm{Y}$ & 50 \\
\hline - Minimal failure and maintenance downtime is achieved & $\mathrm{Y}$ & $\mathrm{Y}$ & $\mathrm{N}$ & $\mathrm{N}$ & 50 \\
\hline \multicolumn{6}{|l|}{ 5) Maintenance manager } \\
\hline - Amount of salary for maintenance manager is satisfactory & $\mathrm{Y}$ & $\mathrm{Y}$ & $\mathrm{N}$ & $\mathrm{Y}$ & 75 \\
\hline $\begin{array}{l}\text { - Specific qualification and experience are required upon employment of } \\
\text { maintenance manager }\end{array}$ & $\mathrm{Y}$ & $\mathrm{Y}$ & $\mathrm{Y}$ & $\mathrm{Y}$ & 100 \\
\hline \multicolumn{6}{|l|}{ 6) Maintenance equipment and technique } \\
\hline - Budget allocated for tools and equipment acquisition is sufficient & $\mathrm{N}$ & $\mathrm{Y}$ & $\mathrm{Y}$ & $\mathrm{N}$ & 50 \\
\hline - Appropriate or advanced maintenance equipment is available & $\mathrm{N}$ & $\mathrm{Y}$ & $\mathrm{Y}$ & $\mathrm{N}$ & 50 \\
\hline - Maintenance tools and technique are fully utilised & $\mathrm{Y}$ & $\mathrm{Y}$ & $\mathrm{Y}$ & $\mathrm{Y}$ & 100 \\
\hline \multicolumn{6}{|l|}{ 7) Acquisition of maintenance data } \\
\hline - Expenses for documentation and recording of maintenance data are allowed & $\mathrm{Y}$ & $\mathrm{Y}$ & $\mathrm{Y}$ & $\mathrm{Y}$ & 100 \\
\hline - Systems condition is accurately reflected by the maintenance data and record & $\mathrm{Y}$ & $\mathrm{Y}$ & $\mathrm{Y}$ & $\mathrm{Y}$ & 100 \\
\hline \multicolumn{6}{|l|}{ 8) Monitoring and inspection } \\
\hline $\begin{array}{l}\text { - Additional budget for monitoring and inspection is allocated (computerised } \\
\text { continuous monitoring system) }\end{array}$ & $\mathrm{N}$ & $\mathrm{N}$ & $\mathrm{Y}$ & $\mathrm{Y}$ & 50 \\
\hline $\begin{array}{l}\text { - Interval of routine inspection is fixed according to criticality of systems and } \\
\text { components (daily, weekly, monthly, yearly, and etc.) }\end{array}$ & $\mathrm{Y}$ & $\mathrm{Y}$ & $\mathrm{Y}$ & $\mathrm{Y}$ & 100 \\
\hline
\end{tabular}

Taking into cognizance the significant maintenance characteristics, this research recommends the practitioners to concern about these characteristics when planning and implementing the maintenance activities. If proper attention is paid to these characteristics, the maintenance performance would most likely be improved.

In order to enhance the effectiveness of maintenance management, contribution and involvements of the key participants, such as the clients, maintenance personnel, and building users in the management is important. Recommendations to improve the effectiveness of management were discussed in the interview sessions. The interviewees suggested that providing communication platform to gather the opinions, comments, needs, and issues of the key participants can improve the planning of maintenance strategies accordingly. For example, the communication platform includes meeting and customer satisfaction survey. Therefore, the commitment and participation of the key participants are necessary in effective maintenance management. 


\section{Conclusion}

This paper describes the background and scenario of building maintenance in Malaysia. Lack of preventive measure is determined as the key issue that implicates poor maintenance performance. In order to tackle the issue, preventive maintenance is introduced in this research. The preventive maintenance characteristics are identified through literature review. Then, the application of the maintenance characteristics are investigated through case study. Eight significant characteristics are demonstrated as the key factors that lead to customers' satisfaction. In other words, those characteristics significantly improve the overall maintenance performance. They are skill and knowledge of maintenance labour, quality of spare parts and materials, length of predetermined maintenance interval, skill and knowledge of maintenance manager, capability to adopt maintenance equipment and technique, budget allocation for acquisition of maintenance data, reliability of maintenance data, as well as frequency of monitoring and inspection. Therefore, this paper recommends the practitioners to concern about these characteristics when planning and implementing the maintenance activities, so that the maintenance performance and customers' satisfaction can be improved and achieved respectively. Provision of communication platforms such as meeting and customer satisfaction survey is suggested to involve all the clients, maintenance personnel, and building users in the planning of maintenance strategy.

\section{References}

[1] Horner, R.M., El-Haram, M.A. and Munns, A. (1997) Building Maintenance Strategy: A New Management Approach. International Journal of Quality in Maintenance, 3, 273-280.

[2] Ruslan, N. (2007) Campus Facilities Management Experience. In National Asset and Facilities Management (NAFAM) Convention, National Asset and Facility Management Development, Kuala Lumpur, Malaysia, 13 August 2007.

[3] Kamaruzzaman, S.N. and Zawawi, E.M.A. (2010) Development of Facilities Management in Malaysia. Journal of Facilities Management, 8, 75-81. http://dx.doi.org/10.1108/14725961011019094

[4] Moghaddam, K.S. and Usher, J.S. (2010) Optimal Preventive Maintenance and Replacement Schedules with Variable Improvement Factor. Journal of Quality in Maintenance Engineering, 16, 271-287. http://dx.doi.org/10.1108/13552511011072916

[5] Wang, W. and Christer, A.H. (2000) Towards a General Condition Based Maintenance Model for a Stochastic Dynamic System. The Journal of the Operational Research Society, 51, 145-155. http://dx.doi.org/10.1057/palgrave.jors.2600863

[6] Chareonsuk, C., Nagarur, N. and Tabycanon, M.T. (1997) A Multicriteria Approach to the Selection of Preventive Maintenance Intervals. International Journal of Production Economics, 49, 55-64. http://dx.doi.org/10.1016/S0925-5273(96)00113-2

[7] Yang, S.K. (2004) A Condition-Based Preventive Maintenance Arrangement for Thermal Power Plants. Electric Power Systems Research, 72, 49-62. http://dx.doi.org/10.1016/j.epsr.2004.03.007

[8] Fouladgar, M.M., Yazdani-Chamzini, A., Lashgari, A., et al. (2012) Maintenance Strategy Selection Using AHP and COPRAS under Fuzzy Environment. International Journal of Strategic Property Management, 16, 85-104. http://dx.doi.org/10.3846/1648715X.2012.666657

[9] Batun, S. and Azizoğlu, M. (2009) Single Machine Scheduling with Preventive Maintenances. International Journal of Production Research, 47, 1753-1771. http://dx.doi.org/10.1080/00207540701636348

[10] Rao, S.S. (1992) Reliability-Based Design. McGraw-Hill, New York.

[11] Eti, M.C., Ogaji, S.O.T. and Probert, S.D. (2006) Development and Implementation of Preventive-Maintenance Practices in Nigerian Industries. Applied Energy, 83, 1163-1179. http://dx.doi.org/10.1016/j.apenergy.2006.01.001

[12] Suttell, R. (2006) Preventive HVAC Maintenance Is a Good Investment. In The Source for Facilities Decision-Makers: Buildings, UNICCO Intergrated Facilities Services, Newton.

[13] Seeley, I.H. (1987) Building Maintenance. 2nd Editon, Palgrave, New York.

[14] Dessouky, Y.M. and Bayer, A. (2002) A Simulation and Design of Experiments Modeling Approach to Minimize Building Maintenance Costs. Computers \& Industrial Engineering, 43, 423-436. http://dx.doi.org/10.1016/S0360-8352(02)00056-6

[15] Kwak, R.Y., Takakusagi, A., Sohn, J.Y., et al. (2004) Development of an Optimal Preventive Maintenance Model Based on the Reliability Assessment for Air-Conditioning Facilities in Office Buildings. Building and Environment, 39, 1141-1156. http://dx.doi.org/10.1016/j.buildenv.2004.01.029

[16] Au-Yong, C.P., Ali, A.S. and Ahmad, F. (2014) Significant Characteristics of Scheduled and Condition-Based Main- 
tenance in Office Building. Journal of Performance of Constructed Facilities, 28, 257-263. http://dx.doi.org/10.1061/(ASCE)CF.1943-5509.0000432

[17] Au-Yong, C.P., Ali, A.S. and Ahmad, F. (2013) Office Building Maintenance: Cost Prediction Model. Gradevinar, 65, 803-809.

[18] Au-Yong, C.P., Ali, A.S. and Ahmad, F. (2014) Prediction Cost Maintenance Model of Office Building Based on Condition-Based Maintenance. Eksploatacja i Niezawodnosc_Maintenance and Reliability, 16, 319-324.

[19] Amaratunga, D. and Baldry, D. (2002) Moving from Performance Measurement to Performance Management. Facilities, 20, 217-223. http://dx.doi.org/10.1108/02632770210426701

[20] Sidwell, A.C. (1990) Project Management: Dynamics and Performance. Journal of Construction Management and Economics, 8, 159-178. http://dx.doi.org/10.1080/01446199000000014

[21] Johnson, J. (1995) Choas: The Dollar Drain of IT Project Failures. Application Development Trend, 2, 41-47.

[22] Parida, A. and Kumar, U. (2006) Maintenance Performance Measurement (MPM): Issues and Challenges. Journal of Quality in Maintenance Engineering, 12, 239-251. http://dx.doi.org/10.1108/13552510610685084

[23] Tucker, M. and Pitt, M. (2009) Customer Performance Measurement in Facilities Management: A Strategic Approach. International Journal of Productivity and Performance Management, 58, 407-422. http://dx.doi.org/10.1108/17410400910965698

[24] Myeda, N.E., Kamaruzzaman, S.N. and Pitt, M. (2011) Measuring the Performance of Office Buildings Maintenance Management in Malaysia. Journal of Facilities Management, 9, 181-199. http://dx.doi.org/10.1108/14725961111148090

[25] Saunders, M., Lewis, P. and Thornhill, A. (2009) Research Methods for Business Students. 5th Editon, Pearson Education Limited, Essex.

[26] Nik Mat, N.E.M. (2009) Performance Measurement of Office Buildings Maintenance Management. Master Unpublished Dissertation, University of Malaya. 